\title{
O Festival e a cidade: 0 exemplo de Avignon
}

The Festival and the city: the example of Avignon

Le Festival et la ville : l'exemple d'Avignon

Jean-Louis Fabiani e Emmanuel Ethis

Tradutor. João Domingues

\section{(2) OpenEdition}

\section{Journals}

\section{Edição electrónica}

URL: http://journals.openedition.org/rccs/1106

DOI: $10.4000 /$ rccs. 1106

ISSN: 2182-7435

\section{Editora}

Centro de Estudos Sociais da Universidade de Coimbra

Edição impressa

Data de publição: 1 Dezembro 2003

Paginação: 07-30

ISSN: 0254-1106

\section{Refêrencia eletrónica}

Jean-Louis Fabiani e Emmanuel Ethis, "O Festival e a cidade: 0 exemplo de Avignon », Revista Crítica de Ciências Sociais [Online], 67 | 2003, colocado online no dia 01 outubro 2012, criado a 02 maio 2019 URL : http://journals.openedition.org/rccs/1106 ; DOI : 10.4000/rccs.1106 


\section{JEAN-LOUIS FABIANI \\ EMMANUEL ETHIS}

\section{O Festival e a cidade: \\ O exemplo de Avignon}

O artigo apresenta uma análise histórica da constituição do Festival de Avignon como grande evento cultural em França. Considerado único pela sua exemplaridade relativamente aos processos de descentralização e democratização cultural preconizados pela política cultural francesa, o Festival é analisado com o objectivo principal de dar conta das ambiguidades que atravessam a definição do seu público. Elaborado com base num trabalho de pesquisa empírica que decorre desde 1996, o artigo põe em evidência alguns dos limites das abordagens dominantes na tradição francófona dos estudos de públicos da cultura. Simultaneamente ilustra as possibilidades de uma abordagem inovadora, que considera os efeitos associados à história dos eventos e aos contextos locais em que estes tomam lugar.

Criado em 1947, o Festival de Teatro de Avignon constitui o maior evento cultural em França. No mês de Julho, durante mais de três semanas, transforma profundamente o espaço urbano convertendo-o numa cidade-teatro. Entre a programação do Festival "in", a instituição oficial, e a do Festival "off", que surgiu nas suas franjas, são apresentadas ao público centenas de espectáculos de natureza variada, desde o "one man show" cómico até ao grande espectáculo que reúne, num palco de grandes dimensões, várias dezenas de actores. Todos os espaços da cidade são requisitados para se tornarem palcos: átrios, igrejas, claustros, mas também a garagem ou a caserna dos bombeiros.

O projecto do Festival de Avignon ergueu-se, desde as suas origens, fixando como objectivo alcançar um modelo original de "fabricar" o seu próprio público. Esta componente do evento, o "público", constitui um dos motores do Festival tal como ele se desenrola nos nossos dias. Público que, durante anos, foi idealizado pela ideologia que impregna o desenvolvimento da cultura do pós-guerra, cuja ambição é tornar esse público popular, e que, por seu lado, não parou de se reinventar, à medida das metamorfoses do Festival. O objectivo inicial de Avignon, reivindicado como tal pela equipa de 
Vilar, ${ }^{1}$ era atrair à antiga cidade dos Papas espectadores até então afastados do teatro, aos quais era preciso incutir o gosto pelo espectáculo vivo e despertar a curiosidade pela arte dramática. "Uma arte colectiva como o teatro não se pode assumir como tal apresentando-se apenas em Paris" - afirma Vilar. Para isso, é necessário estar em condições de "reunir nas galerias da comunhão dramática, o pequeno comerciante e o alto magistrado, o operário e o agente de câmbio, o carteiro dos pobres e o professor catedrático" (Vilar, 1953: 27). Assim se constrói a lenda de Avignon e do seu público. Fugindo aos teatros fechados, o teatro do Festival afirma-se doravante como plenamente urbano, muito antes de se tornar um programa político estabelecido e de assumir o estatuto de experiência exemplar e simbólica de descentralização cultural. Esta fórmula de "festival" estendeu-se rapidamente a outras cidades francesas, tornando-se, de forma duradoura, um verdadeiro instrumento de organização cultural do território. A tríade - espectáculos em cenários urbanos libertos dos constrangimentos do espaço teatral especializado, cidade de província, reutilização do património - constitui o fundamento deste modelo. Aí reside, pensamos, uma das chaves de sucesso da fórmula "festival" junto deste público que, desse modo, pode frequentar a cultura em "mangas de camisa". Estes espectadores em "mangas de camisa" contribuíram significativamente para o reforço da ideia de que estas manifestações estivais podiam apagar as diferenças sociais que o teatro gera.

Entretanto, a ideia da indiferenciação social como suporte de uma comunidade de espectadores finalmente reunida colapsa quando, em 1968, são publicados, no suplemento dos Cabiers du Conseil Culturel d'Avignon-Expansion, os resultados do primeiro inquérito sociológico aplicado ao público do Festival por uma socióloga do Centre National de la Recherche Scientifique, Janine Larrue (1968). Jean Vilar assina o prefácio deste trabalho. Evoca, sem a nomear, uma "sombra" que paira sobre todas as tabelas com os dados do inquérito e sobre as conclusões do mesmo:

Eis, finalmente, um inquérito sério sobre o Festival de Avignon. Eis, finalmente, dados concretos. Em suma, eis, finalmente, um assunto para reflectirmos sem ilusões e, em definitivo, nos alegrarmos. Muito há a reter deste estudo de Janine Larrue. Nomeadamente, que movimento e permanência são as duas características destas manifestações de Verão. Com efeito, se $17 \%$ dos 6000 espectadores que responde-

\footnotetext{
${ }^{1}$ Jean Vilar, nascido em 1912, em Sète, escolheu tornar-se encenador depois do encontro que teve com Charles Dullin, antes da Segunda Guerra Mundial. Conhecido pelas suas encenações de Strindberg, de Synge, e sobretudo de Assassínio na Catedral, de T. S. Eliot, criou o Festival de Avignon em 1947 e dirigiu o Teatro Nacional Popular, no Palácio de Chaillot, em Paris, de 1951 a 1963. Morreu em 1971, depois de ter incarnado, durante um quarto de século, o teatro público.
} 
ram ao questionário voltam todos os anos - e o Festival conta já 22 anos de existência - deve assinalar-se que $48 \%$ vieram pela primeira vez ao Festival no ano passado. E que dizer destes dados que o inquérito de Janine Larrue nos fornece: que 64\% dos espectadores têm menos de 30 anos. E $82 \%$ menos de 40 anos. Ah! Há uma sombra que paira sobre todas as tabelas do inquérito e sobre as suas conclusões. Deixo ao leitor o cuidado ou a preocupação de a descobrir. Muito fizemos nós em 22 anos para a atenuar.

Para terminar, lamento que um inquérito deste tipo não tenha sido aplicado de $3 \mathrm{em}$ 3 ou de 5 em 5 anos, desde as origens do Festival. Os dados obtidos por essa via teriam facilitado o nosso trabalho, teriam agido de forma concreta sobre a nossa reflexão, teriam permitido realizar um trabalho mais extenso no plano social, nomeadamente no que diz respeito às classes mais desfavorecidas. Teríamos, talvez, escolhido outros caminhos. Mas que outros? Seriam assim tão fáceis de descobrir? Tê-los-íamos acrescentado aos que traçámos? Honra seja feita a Janine Larrue. (Vilar, 1968)

Esta sombra, que Vilar propõe aos leitores do inquérito que sejam eles próprios a descobrir, é - como poderá adivinhar-se desde já - a reduzida proporção de operários e de empregados que frequentam o Festival, o que obriga a que o evento, que continua a ter um sucesso indesmentível, proceda ao reajustamento do sentido da palavra "popular", sobre a qual se ergueu. A maior virtude do realismo sociológico do inquérito aplicado aos espectadores não reside, porém, nesta deflação ideológica, mas sim no convite à reflexão que podemos resumir numa única pergunta: qual é, na realidade, o público do Festival? É esta a questão a que este artigo tenta responder. Apoiando-se num inquérito sociológico aplicado entre 1996 e 2001 aos espectadores do Festival, a exploração analítica que aqui é proposta visa captar, a partir de vários ângulos de abordagem, as características comuns daqueles que participam na manifestação estival. Trata-se de um público de teatro sociologicamente equivalente ou diferente daquele que, em geral, encontramos nas salas? É animado por motivações particulares? $\mathrm{O}$ que procura em Avignon que não pudesse encontrar noutro local? As observações que se seguem, produzidas a partir de um inquérito quantitativo e de uma observação etnográfica realizados entre 1996 e 2001, ${ }^{2}$ oferecem uma tentativa de resposta a estas questões.

2 As observações desenvolvidas neste artigo apoiam-se numa investigação conduzida por É. Ethis, J.-L. Fabiani e E. Pedler desde 1995 (para uma revisão completa ver Éthis, 2002). A investigação associou a aplicação de um questionário à saída dos espectáculos a uma amostra de cerca de 2000 espectadores, a uma pesquisa etnográfica baseada na observação directa e a entrevistas aprofundadas com cerca de 200 espectadores. Esta investigação continua a ser realizada entre 2003 e 2005 sob a direcção de J.-L. Fabiani: o seu objectivo é promover uma pesquisa sociológica estruturada no tempo e desenvolver novas vias de investigação que envolvam, nomeadamente, os espectadores jovens. 


\section{O teatro e a acção pública}

O Festival de Avignon ocupa um lugar ímpar na história cultural francesa. Ele ilustra, no mais elevado grau, a aliança entre uma política cultural de Estado e uma mobilização artística. A política do imediato pós-guerra não incluiu explicitamente, entre os seus objectivos, nem o alargamento dos públicos, nem a transformação do território através da oferta cultural. Só com a formação do Ministério de André Malraux, em 1959, é adoptada uma lógica de acção que, preconizando esses dois objectivos, mostra estar devidamente concebida e sustentada em argumentos. Sendo que, desde a época da Frente Popular (1936), o teatro se tornara o paradigma de um sector cultural que a acção pública pode e deve transformar. O teatro pertence, de facto, em simultâneo, ao mundo do lazer e ao mundo da acção pública. Ele é, ao mesmo tempo, festa e organização discursiva, jogo, ritual e demonstração. Ocupa o papel principal na celebração das ideias (particularmente da ideia de nação, mas também da de assembleia popular).

Desde as Luzes, até Romain Rolland, passando por Michelet, o teatro apresenta-se como a figuração da democracia: o povo reunido vê-se representado nele, vê nele a evidência do seu poder colectivo, e confirma através dele o sentido da sua existência. A noção de ar livre desempenha, desde as origens, um papel central: o céu estrelado constitui o cenário privilegiado da "comunhão laica", longe das presunções do teatro de corte ou da frivolidade do teatro burguês. Pascal Ory salienta que

a Primeira República tinha instituído um Teatro do povo: a obra escrita de um Romain Rolland e a obra cénica de um Firmin Gémier eram, no início do século XX, emblemas da política cultural da esquerda dreyfusiana no mesmo plano das Universidades populares. (Ory, 1994: 337)

Se a noção de política cultural se afigura aqui um pouco arriscada, não deixa de ser verdade que é numa forma de continuidade ideológica que associa a noção de teatro à noção de povo que podemos interpretar toda a história do teatro público ao longo do século XX. O carácter eminentemente político do teatro permite explicar todos os investimentos passionais de que viria a ser objecto quando surge a questão do alargamento dos públicos e da transformação da sua relação com os bens culturais. Nenhuma forma de arte alcançou o mesmo estatuto, ainda que a questão do alargamento das assistências se tenha colocado em todas as disciplinas artísticas no momento em que se impôs uma administração nacional da cultura. Esperava-se do teatro que ele fosse o motor de transformação da relação que 
existe entre a obra, o autor e o público, a tal ponto ele se mostrava próximo da manifestação de uma espécie de comunidade cultural, assumindo-se como modelo reduzido do povo reunido em assembleia, ou pelo menos como promessa de uma assembleia popular que haveria de emergir.

No que respeita à mobilização artística, que à época da Frente Popular é praticamente indissociável da vontade política dos eleitos e da administração, ela é também uma característica permanente da vida teatral ao longo do século. Desde o primeiro quartel do século XX, como lembrou Robert Abirached (1992), os criadores do novo teatro associaram nos seus manifestos reivindicações de três ordens, misturando, de forma inextricável, estética e política. É assim que três grandes temas se encontram ligados. O primeiro é o do teatro popular, o segundo é o de uma reforma da prática artística e o terceiro é o da descentralização.

A reivindicação do estatuto de teatro popular não implica necessariamente a obrigação de se dirigir uniformemente a todas as categorias sociais, nem sequer a criação de um repertório que possa ser compreendido por todos. A reivindicação incide, sobretudo, sobre a degradação do teatro parisiense que se encontrava então quase completamente reduzido à sua dimensão de lazer burguês: as reivindicações, frequentemente expressas numa linguagem polémica, incidem sobre a falta de qualidade artística do teatro de divertimento. $\mathrm{O}$ burguês incriminado é muito menos o de Marx que o de Flaubert. Jacques Copeau denuncia energicamente a "mediocridade, a baixeza, o bluff, o exibicionismo, a cobardia" do teatro parisiense. O povo que deserta do teatro é, aliás, o povo culto: é o que claramente é revelado quando Copeau denuncia "a industrialização desenfreada que degrada os nossos palcos franceses e desvia deles o público culto" (Abirached, 1992: 16).

O início do século vê acentuar-se o fosso entre o teatro comercial (nas mãos de empresários privados que bajulam o público burguês, oriundo dos mundos da economia e do comércio, alimentando os seus gostos) e o teatro de criação (que encontra os seus primeiros apoios no seio da Universidade e das vanguardas intelectuais). A reivindicação do teatro popular no primeiro quartel do século exprime, simultaneamente, a recusa de uma prática artística (se é que ainda merece esse nome) fundada na satisfação rotineira das solicitações de um público sem apetite cultural: a cidade de Paris, como o teatro à italiana e a sua sociabilidade adulterada, é identificada com a corrupção imbuída na própria ideia de teatro. A recusa do luxo, do brilhante, do cenário e a exigência de frugalidade e de ascese exprimem, ao contrário, a ambição do artista, cuja missão não é satisfazer solicitações, mas assegurar a autonomia do seu gesto criador. $\mathrm{O}$ facto de o teatro não 
poder abdicar nem de recursos, nem de público, ao contrário do que acontece com outras formas de expressão artística, levou a que os criadores do novo teatro tenham sido instigados a criar um público. O público popular, que nunca é definido na sua composição sociológica, mas que se afirma como uma alternativa teórica ao condenável público burguês. É, porém, claro que este público não existe enquanto tal e que é necessário produzi-lo, transformando simultaneamente a prática do espectador, do encenador e do actor, no mesmo sentido em que se transforma a prática do encenador e do actor. A produção do espectador, implícita mas essencial nos discursos dos jovens criadores da primeira metade do século XX, vai incarnar na realidade por via de um alargamento geográfico da população abrangida. Se o teatro burguês é dominante em Paris, é necessário ir montar o palco em outro sítio, onde a experiência do espectador não seja afectada pela oferta mercantil de divertimento. A procura de um público sonhado, ou reinventado, vai exprimir-se através da noção de descentralização (que prefigura, sem que a ela se sobreponha, a ideia ulterior de um verdadeiro ordenamento cultural do território).

Como vemos, a exigência ideológica de uma transformação da composição do público ou da sua relação com as obras desempenha um papel secundário na configuração do teatro de criação no decurso da primeira metade do século: os criadores centram as suas reivindicações na autonomização do seu gesto de artistas e combatem o público burguês porque as expectativas deste público os mantêm na heteronímia de uma prática servil. O outro público, por eles tão desejado, é, de um certo modo, uma ficção, assente na ilusão de que as disposições culturais podem ser duradouramente modificadas por via da influência da descoberta de um novo continente cultural. Se o teatro manteve, durante muito tempo, relações de proximidade com a política, na medida em que ambos se afirmam pelo pronunciamento de palavras públicas, não deixa, por isso, de ser verdade que o apelo à constituição de um novo público, mais atento à criação porque afastado do lazer burguês, constituiu um dos grandes mal-entendidos culturais do século XX. O novo público, em relação ao qual se mantém a expectativa de o vermos manifestar-se no teatro de criação, é uma espécie de ficção metodológica destinada a garantir a autonomia do artista. Ora, a autonomização absoluta do gesto artístico implica a ruptura de qualquer pacto de recepção com o público. Não pode ser dado por garantido que o público das classes "populares", no sentido sociológico do termo, aceite mais facilmente do que os burgueses as convenções do teatro de criação. Podemos mesmo afirmar que quanto mais o artista se autonomiza menos tem necessidade do público. E, no entanto, o teatro não existiria sem a 
presença do público. A tensão que se instalou entre o público sonhado e o público real esteve na origem da criação do teatro popular. Podemos encontrá-la recorrentemente na sociologia histórica das audiências. É, no entanto, espantoso constatar que as polémicas continuam vivas à volta da questão do alargamento dos públicos, quando as constatações sociológicas documentam sem cessar o carácter socialmente restrito do público do teatro, ainda que público e etiquetado como popular.

\section{Os novos caminhos da pesquisa}

O mito do teatro popular vê-se hoje confrontado, mais do que com a questão lancinante do malogro da democratização cultural, com outras formas de experiência e de justificação do espectáculo ao vivo.

Do teatro, o que declinou durante estes últimos vinte anos foi a mitologia; mitologia alimentada pelo grande desejo do corpo social que uma arte ou uma actividade podem gerar. O teatro, apesar de excepções brilhantes, já não pertence a este campo maioritário e apresenta-se ou assume-se mesmo como uma actividade minoritária. (Banu, 1993: 97)

Sem convidar necessariamente a subscrever o ponto de vista deste notável autor, que pensa que "o que está a enfraquecer é o desejo de ir ao teatro e não o de fazer teatro", e diagnosticando antes uma oscilação do diferencial que separa o desejo de ir ao teatro das formas da oferta que o reanimam, a nossa pesquisa poderá ser lida como uma contribuição, insuficiente, sem dúvida, para o estudo das relações entre o mito fundador e as práticas efectivas que estão, seguramente, muito afastadas das dos pioneiros, mas mantêm com elas uma relação de referência ou de simples citação que constitui a originalidade deste lugar. Os sociólogos obedecem ao princípio da realidade: o seu trabalho consiste em apresentar o tratamento dos dados sem maquilhagens. Mas eles conhecem também o peso e o preço das mitologias fundadoras, que continuam a conferir uma boa parte do seu sentido a práticas intermitentes ou disseminadas.

Os estudos sociológicos consagrados à frequentação do teatro em França não são muito numerosos. Em 1996, altura em que começámos o nosso estudo sobre o Festival, não dispúnhamos senão de inquéritos relativamente antigos e, para mais, efectuados à escala nacional, o que não permitia obter elementos de comparação com as situações locais. Recentemente, a publicação de Publics de la Comédie Française, fréquentation et image de la salle Richelieu (Beaudoin e Maresca, 1998) modificou sensivelmente o contexto no seio do qual tomava então lugar o nosso inquérito. Este estudo monográ- 
fico insere-se numa perspectiva mais ampla: trata-se de orientar os inquéritos futuros sobre outros teatros franceses. ${ }^{3}$ Podemos, pois, inscrever a reflexão na perspectiva de diálogo aberta pelo estudo.

As análises das práticas culturais privilegiaram, durante muito tempo, em virtude das comodidades que a recolha e o tratamento dos dados da frequentação ofereciam, um processo de simples enumeração: o sentido da prática encontrava-se completamente enclausurado na medida da sua frequência e da sua intensidade, sendo, deste modo, a noção de frequentação reduzida à expressão mais simples. Seria errado ver nesta redução à contagem das audiências uma simples disposição técnica: ela exprime também uma lógica política do uso dos números que centra a questão em torno da estratificação social dos públicos e da igualização das condições de acesso aos bens culturais. Agindo assim, os sociólogos foram levados a propor, ainda que nem sempre a controlassem verdadeiramente, uma visão "realista" do público de teatro: este existiria independentemente dos limites da representação e poderíamos atribuir à sua existência um certo número de funções sociais (por exemplo, o uso realista da noção de público seleccionado permite ilustrar uma teoria da distinção ou da notabilidade cultural, mesmo se a base estatística destas conceptualizações é notoriamente frágil). Não é forçar a nota lembrar que aquilo a que chamamos "público" não existe senão nos limites da representação e que o objecto do sociólogo não pode ser buscado em outro lado a não ser nas assistências sucessivas de representações singulares.

Os modos de existência destas assistências efémeras são, aliás, múltiplos: nem todas as representações produzem os mesmos efeitos. Se algumas podem ser pensadas como simples agregação de átomos individuais, na perspectiva aberta pelo individualismo metodológico, outras devem ser analisadas tendo por base os efeitos de integração ou de composição originais que produzem: existe uma dinâmica própria das assistências, um clima característico de cada uma delas, como bem sabem os actores e os encenadores. Os sociólogos, as mais das vezes, são indiferentes a esta questão. São-no um pouco menos à questão dos princípios que produzem a divisão interna das assistências singulares: mas a não-homogeneidade do público, que pode manifestar-se pela existência de formas de luta ou de competição no seu seio, raramente está no centro das preocupações. Objectar-se-á a este ponto de vista que a aproximação à realidade da experiência de espectador gera

\footnotetext{
3 No prefácio que faz a este livro, Jean-Michel Guy sublinha que o relatório do inquérito sobre os públicos da Comédia Francesa procurava responder "a uma preocupação antiga da direcção do teatro e dos espectáculos do Ministério da Cultura e da Comunicação, que desejava aperfeiçoar um protocolo de inquérito no qual pudessem inspirar-se os teatros desejosos de conhecer melhor os seus espectadores" (Beaudoin e Maresca, 1998: 11).
} 
custos de investigação enormes para resultados que correm o risco de não se revelar à altura dos esforços empreendidos, como mostraram certas tentativas de refundação da cultura em torno da noção de recepção.

Mas voltemos ao terreno de Avignon. A nossa primeira preocupação levou-nos a perguntarmo-nos se um festival de renome internacional gerava uma nova temporalidade, a ponto de introduzir perturbação nas práticas locais (à escala dos teatros instalados nas principais cidades francesas), criando uma oferta à qual não corresponde nenhum outro dispositivo. Assim, uma fracção consequente dos frequentadores do festival assiste, efectivamente, a mais espectáculos apenas durante o mês de Julho do que durante o resto do ano. Nessa medida, pelo menos, um festival não assegura, pois, uma simples deslocação de práticas já existentes; delimita, pelo contrário, um novo espaço de partilha. Tratava-se, graças a este inquérito, de quantificar este efeito e de revelar os tipos de complementaridade que se estabelecem entre as ofertas locais e do festival, interessando-se, de modo especial, pelo espaço regional Provença-Alpes-Côte d'Azur. Necessário se torna acrescentar que só o estudo caso a caso - isto é, festival a festival - permite objectivar este tipo de funcionamento, dado que não parece existir qualquer regra geral neste domínio.

Nesta perspectiva, podemos avançar a hipótese de que o dispositivo do festival está dotado de um efeito dinâmico próprio capaz de instaurar uma circulação, se não mesmo, em certos casos, uma renovação dos públicos. Os teatros implantados nos grandes centros urbanos têm a reputação de exercer um efeito de intimidação por se presumir a presença de "notáveis culturais" que constituiriam a fracção mais estável dos seus públicos. Mais genericamente, as barreiras que limitam as saídas urbanas para lugares de espectáculo contribuem para a filtragem dos espectadores. $\mathrm{O}$ inquérito do ministério francês da Cultura sobre Les publics du théâtre, realizado por Jean-Michel Guy e Lucien Mironer (1988), permitiu, a este respeito, compreender que a relação com o lugar (desde as salas à italiana até às cenas improvisadas nas ruas) ou com as convenções (reservar, vestir-se, instalar-se na sala) variava de um grupo de espectadores para outro. Uma das conclusões deste relatório levava, deste modo, a identificar a existência de desejos de saída não satisfeitos, contrariados por diversas características da oferta. A respeito da questão colocada, na altura de um inquérito realizado igualmente por Jean-Michel Guy (1991) - desta vez a propósito de espectáculos de dança -, que visava perguntar aos espectadores se iriam a um espectáculo que lhes fosse oferecido, as respostas negativas atingiram proporções apreciáveis da população inquirida, mostrando, assim, que existem também, e significativamente, atitudes de indiferença que o sociólogo é por vezes 
tentado a ignorar ou a menorizar. É preciso, sem dúvida, estender a influência destes comportamentos ao desejo de ver ou de ter visto - nem que fosse uma única vez - um tipo de espectáculo, a fim de satisfazer o único e vago desejo de ficar a saber do que se trata.

Seja como for, o Festival de Avignon, na sua singularidade, parece oferecer diversas oportunidades às curiosidades que talvez se não tivessem convertido por via do contacto com o programa de um teatro municipal, uma vez que parece claramente desempenhar o papel de banco de ensaio para as fracções mais jovens dos públicos, tal como podia depreender-se do inquérito prévio efectuado em Avignon em 1995 e como confirmam os resultados para 1996 e para os anos seguintes.

\section{Um perfil de público particular}

O inquérito sobre o Festival de Avignon apresentado no nosso estudo (Éthis, 2002) permite-nos falar, com outras armas, da questão do teatro público. Podemos, evidentemente, facilitar-nos a vida confrontando, termo a termo, o velho discurso de Vilar sobre a fusão de todas as camadas sociais no seio de um público enfim comunitário sob o céu estrelado do Verão provençal com as estatísticas de frequentação. Rigorosamente falando, um festival plenamente democrático é uma manifestação na qual a composição do público deveria corresponder, quase na perfeição, à estrutura sócio-demográfica da região. Ora, nada mais falso, como sabemos. Assim sendo, a questão do teatro enquanto serviço público deve ser colocada novamente, se considerarmos com atenção a estrutura da assistência de Avignon. Uma das especificidades deste público é o facto de reunir muito poucos dos que poderíamos chamar, por comodidade, "notáveis" urbanos. Reagrupados, professores, profissões científicas, profissões do âmbito da informação, artes e espectáculos, professores primários e seus congéneres, alunos e estudantes, formam $60,6 \%$ da amostra, enquanto estes grupos não chegam a representar um terço desta percentagem na população activa com mais de quinze anos. É a constatação mais surpreendente do nosso inquérito, que permite, por exemplo, diferenciar nitidamente o público de Avignon do da Comédia Francesa.

Se as profissões técnicas e de enquadramento (com níveis superiores de educação) representam $48,5 \%$ da nossa população, contra $6 \%$ (segundo o recenseamento de 1990) na população francesa, as profissões liberais, os quadros de empresa, os quadros administrativos e comerciais de empresa, os engenheiros e quadros técnicos de empresa só muito levemente contribuem para o aumento dos profissionais técnicos e de enquadramento na nossa amostra (formam 12,2\% dos 48,5\%, contra 19\% no inquérito sobre 
a Comédia Francesa). Estas constatações permitem colocar novamente a questão da singularidade do Festival de Avignon. É claro que o conjunto destes números não permite encontrar os "efeitos de notabilidade" ligados às práticas culturais urbanas mais distintivas, tal como surgem no caso da frequentação da Ópera ou dos grandes estabelecimentos do tipo da Comédia Francesa. Os públicos de Avignon são o produto de uma história particular. Descentralizado numa cidade que não é um dos grandes pólos urbanos franceses e concentrado num curto período estival, o Festival não pode ser completamente avaliado a partir dos efeitos de "notabilidade cultural". É, em parte, a uma outra lógica que é preciso atribuir o modo de agregação particular dos públicos de Avignon. Sem jogar com as palavras, poderíamos relacionar a noção proposta por Jean Vilar de teatro como serviço público e a sobre-representação das profissões do sector público no seio dos frequentadores de Avignon. Diferentemente do que se passa em outros grandes encontros europeus, o Festival não pode ser considerado como um encontro estival de "notáveis" culturais, antes corresponde a uma concentração temporária dos amigos do teatro público. ${ }^{4}$

Podemos afirmar que o Festival de Avignon não constituía uma oferta entre outras, num conjunto de actividades estivais de lazer cultural que pudéssemos avaliar comparativamente. $\mathrm{Na}$ escolha das obras pelos espectadores, discernimos uma relação global com a cultura, uma atitude intelectual e afectiva fundada no reconhecimento implícito de valores comuns entre os espectadores e os organizadores. A especificidade de uma organização deste tipo é o facto de ela associar rituais recorrentes à reivindicação de inovação e de ruptura. A tranquilidade que a estabilidade de lugares e de ritos concede coexiste com a ideia de que se encontra em Avignon algo que se assemelha a um laboratório de experimentação cultural. A esse título, o Festival possui alguns dos traços que caracterizam as grandes instituições culturais sazonais, mas diferencia-se delas pelas expectativas implícitas de uma boa parte do público: vem-se a Avignon, num espírito de concentração e de rigor, para se ser informado sobre o estado em que se encontra o Teatro. Neste aspecto, embora as condições objectivas do acesso às obras e a natu-

\footnotetext{
${ }^{4}$ A proximidade entre o teatro público e a função pública em França tem várias explicações. A primeira é o facto de o poder central ter assumido precocemente responsabilidades pela cultura, o que fez emergir uma preocupação pública pelas questões culturais e, consequentemente, a constituição de uma verdadeira administração da cultura. A segunda é a constituição, no seio da função pública francesa, numérica e socialmente importante desde a "perenização" da República, de uma temática da emancipação (e da igualização das condições) pelo acesso à cultura, de modo particular na altura da Frente Popular (1936). A terceira é a forte integração das questões culturais no conjunto das crenças partilhadas que fundam a ideologia do serviço público. Sobre a questão da clivagem público/privado, é de referir a obra de François de Singly e Claude Thélot (1989).
} 
reza da oferta tenham sido profundamente transformadas desde o imediato pós-guerra, observa-se uma certa continuidade com o Festival das origens. A grande diversidade de lotações que caracteriza a oferta de espectáculos (de sessenta a quinze mil lugares disponíveis) constitui um princípio de hierarquização e de orientação do público.

É manifesto que existe uma nítida convergência entre as previsões dos organizadores e a deslocação das multidões. A lotação, os lugares e o número de sessões programadas constituem como que um quadro interpretativo: cada lugar tem o seu ambiente, as suas cores, mas também a sua "tradição" oral de representação. Neste domínio, a memória individual apoia-se nos quadros da memória colectiva para constituir um espaço de decisão pensada. Nesta configuração, ganham sentido informações adicionais sobre a obra, o autor, o encenador, os intérpretes. Estes dispositivos permitem tornar o desconhecido conhecido ou, pelo menos, cognoscível. As previsões felizes dos espectadores, que permitem que a predição se realize, não podem ter lugar se um certo grau de saber tácito não for comum aos programadores e aos candidatos a espectadores.

Deste inquérito ressalta, por fim, uma série de indicadores sobre o que pode ser definido como uma forma da relação contemporânea com a cultura dita "legítima". A oferta teatral é apreciada com uma boa vontade isenta de excesso de zelo, a fidelidade a uma instituição não conduz a uma devoção do tipo religioso. Nesta matéria, são as analogias fáceis com a experiência religiosa (era, decerto, ironicamente que Morvan Lebesque ${ }^{5}$ falava de "peregrinos" aquando dos primeiros festivais), para caracterizar a relação com o teatro, que são inadequadas, mas também a noção prévia que vê em todo o festival uma assembleia de grandes notáveis. Avignon não é nem Bayreuth nem Fátima. Para compreender bem Avignon, será preferível referirmo-nos à história e à geografia de um lugar sem mais exemplos do que às teorias da distinção ou da notabilidade cultural. A este propósito, é ainda importante determo-nos sobre o coração da "cidade-festival" - o Pátio de Honra - que reúne as maiores concentrações de espectadores e representa, urbi et orbi, a própria essência do Festival.

\section{No coração da "cidade-teatro": o Pátio de Honra}

Situado no interior do Palácio dos Papas, o Pátio de Honra é, ao mesmo tempo, o lugar original do Festival e o seu espaço cénico mais prestigiado. Quando ritualmente se abre o Festival e o Pátio de Honra "oculta" o pátio,

\footnotetext{
${ }^{5}$ Apud Lerrant, 1996: 66. Morvan Lebesque (1911-1970), jornalista, ficou conhecido pelas suas crónicas no semanário satírico Le Canard enchainé. É autor do Retrato de Albert Camus e de Como se pode ser bretão?
} 
o mito readquire os seus direitos. Quer sejamos encenadores ou actores, críticos ou "simples" espectadores, quando nos preparamos para "actuar no Pátio de Honra" ou para "ir ao Pátio de Honra", sabemos de imediato que vamos participar numa prova, no sentido mais activo do termo. Entrar no Pátio é aceitar penetrar temporariamente numa espécie de poço gigante, onde os elementos naturais, o mistral, a poeira e o frio surgem como fantasmas vindos do passado para medir forças com os actores de carne e osso. De resto, nenhuma representação que se faça no Pátio existe por si própria. Todas são comentadas com apelo a necessárias comparações com outras que, melhor ou pior, habitaram esse lugar.

$\mathrm{Na}$ verdade, nenhum teatro em França pode considerar-se depositário do passado a este ponto. É lá, sem dúvida, que se revela a singularidade de Avignon, impregnada nesse Pátio onde uma comunidade de espectadores, sempre a reunir, nunca deixou de reactualizar o gosto fértil pela nostalgia. De facto, hoje ninguém pode sair do Pátio considerando-se plenamente saciado ou inteiramente satisfeito. O Pátio tornou-se um símbolo que desafia a própria realidade do acto teatral - a do actor e a do encenador, como a do espectador -, interrogando com veemência o sentido actual de "estar no teatro". É lá que se precipita e se resume o Festival nos seus contrastes mais acentuados, os mesmos que lhe conferem a mais forte vitalidade:

O mais impressionante aqui é a heterogeneidade do público. O público da estreia, onde os críticos se misturam com a população local, é o mais rude. [...] Ao longo dos dias, o espectáculo melhora e o público homogeneiza-se. O Pátio de Honra amplifica tudo: os sucessos tal como os insucessos. As feridas são aí mais profundas e mais vivas do que em qualquer outro lugar. (entrevista com Bernard Faivre d'Arcier, director do Festival, número especial de Télérama, 2001)

O Pátio mantém-se como o local onde se encontram, num dia ou noutro, todos os espectadores do Festival de Avignon. Ocupar o seu lugar no Pátio é também ocupar uma posição particular na arquitectura geral do lugar. Também aí fez obra a ideologia das origens, racionalizando, ao longo do tempo, o dispositivo de indiferenciação do público. Em 1951, Vilar declarava:

Em vez de unir, a arquitectura das salas actuais divide. É preciso ter consciência de que o teatro não é apenas um divertimento, não é um objecto de luxo, mas uma necessidade imperiosa de todo o homem e de toda a mulher. (Vilar, 1953)

A invenção da tradição, tal como se vive em Avignon, visa uma abolição das desigualdades que presidem à repartição dos espectadores nas salas 
fechadas (orquestras, camarins, camarotes, galerias...). Mas nem sempre foi assim. Em 1947, o palco foi montado com recurso a cavaletes montados sobre bidões de gasolina e carris do caminho-de-ferro. Todos os espectadores se sentavam em pequenas cadeiras de jardim, do mesmo modelo, distintamente separadas por meio de barreiras em função das categorias de preços.

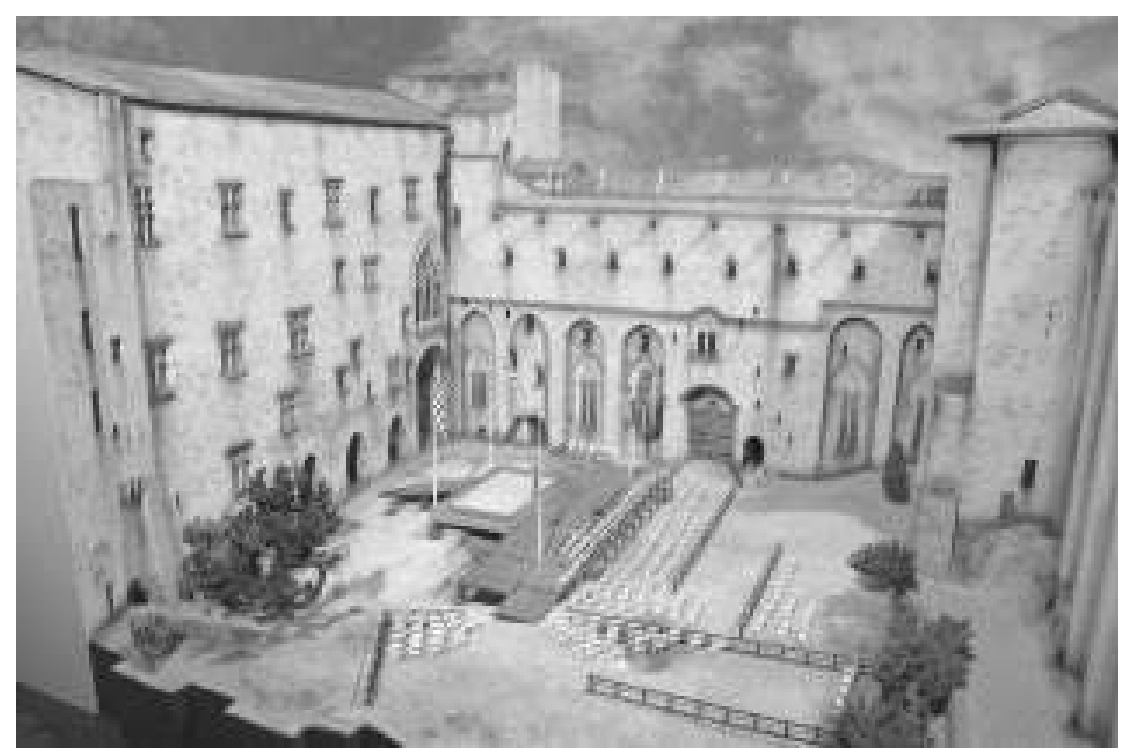

Maqueta do Pátio de Honra de 1947

Em 1949, surgem, colocados diante dos bancos, alguns cadeirões e camarotes.

Depois, quando surgiram as bancadas, nunca mais houve na plateia senão bancos de encosto, de madeira, com excepção de alguns cadeirões. A diferença entre as bancadas e a plateia estava bem marcada, mas as barreiras tinham sido suprimidas e, da mesma forma, também as discriminações embaraçosas. (Arlaud, 1969)

Concebida em primeira mão para a dança e os espectáculos de Maurice Béjart, a nova sala de 1967 tende, cada vez mais, para a uniformidade e todos os espectadores beneficiam do mesmo tipo de assento, seja qual for o seu lugar. Os preços variam apenas em função do afastamento relativamente ao palco. A disposição de todos os lugares obedece à mesma inclinação. O mesmo princípio prevalece na construção do Pátio, em 1982, que chegará a reunir 2250 espectadores, mesmo se, para possuir tal capaci- 
dade, foi preciso instalar galerias. Estas, claro está, não deixaram de dar, como bem sublinhou o cenógrafo Guy-Claude François, "uma sensação de asfixia". ${ }^{6}$

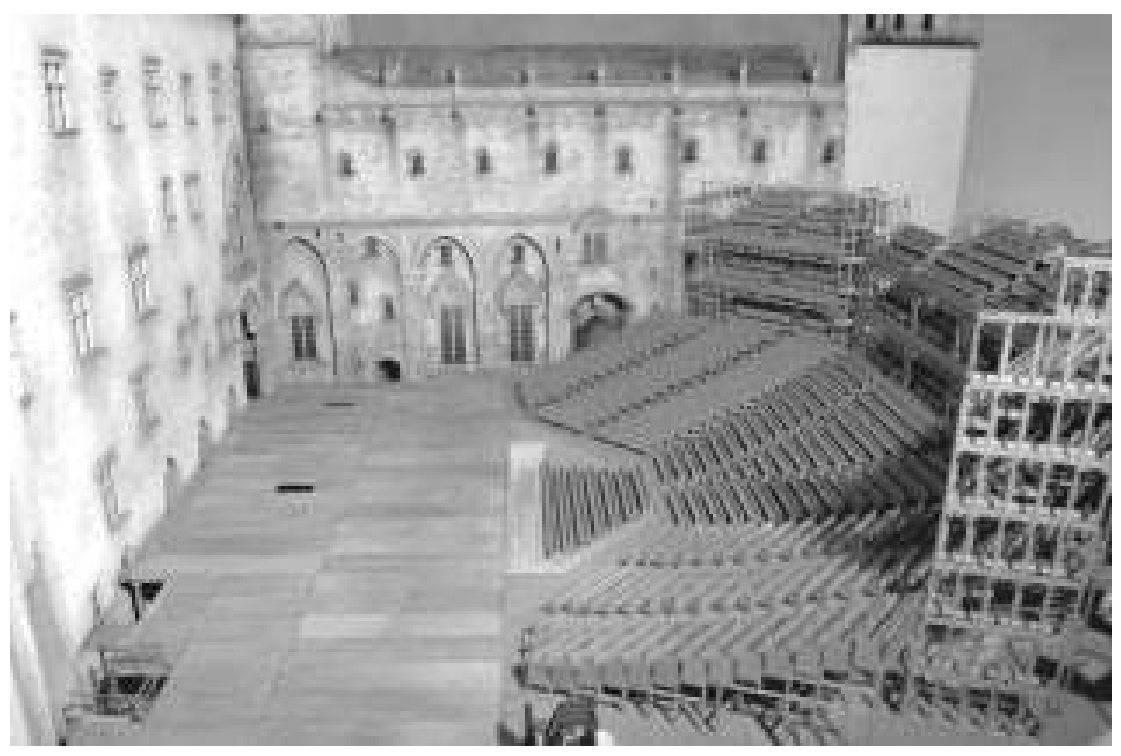

Maqueta do Pátio de Honra de 1982

O novo Pátio que foi instalado vinte anos depois, em 2002, comporta um pouco menos de dois mil lugares. Hoje, diz Guy-Claude François,

[...] é um lugar que me agrada porque não foi concebido por um arquitecto. Sente-se que é uma arquitectura que foi sendo construída à medida da vida, dos acontecimentos, dos desejos [...]. Este Pátio faz parte de um conjunto de vários lugares no mundo, e em particular na Europa, que nos colocam sempre o mesmo dilema: ou faço com ou faço contra. Ou se reforça o que ele é, acrescentando elementos que teatralizem e correspondam funcionalmente ao espectáculo sobre o qual trabalhamos, como se o Pátio tivesse sido feito para ele; podemos, por exemplo, acrescentar pedaços de muralha. Ou então fazemos contra, jogando com os constrangimentos. Neste caso, é iconoclasta. As duas modalidades são válidas. Mas não se deve ter medo disso. (Entrevista com Guy-Claude François, dossier de imprensa do Festival, 2002)

\footnotetext{
${ }^{6}$ Entrevista a Guy-Claude François, dossier de imprensa do Festival, 2002.
} 
22 | Jean-Louis Fabiani e Emmanuel Éthis

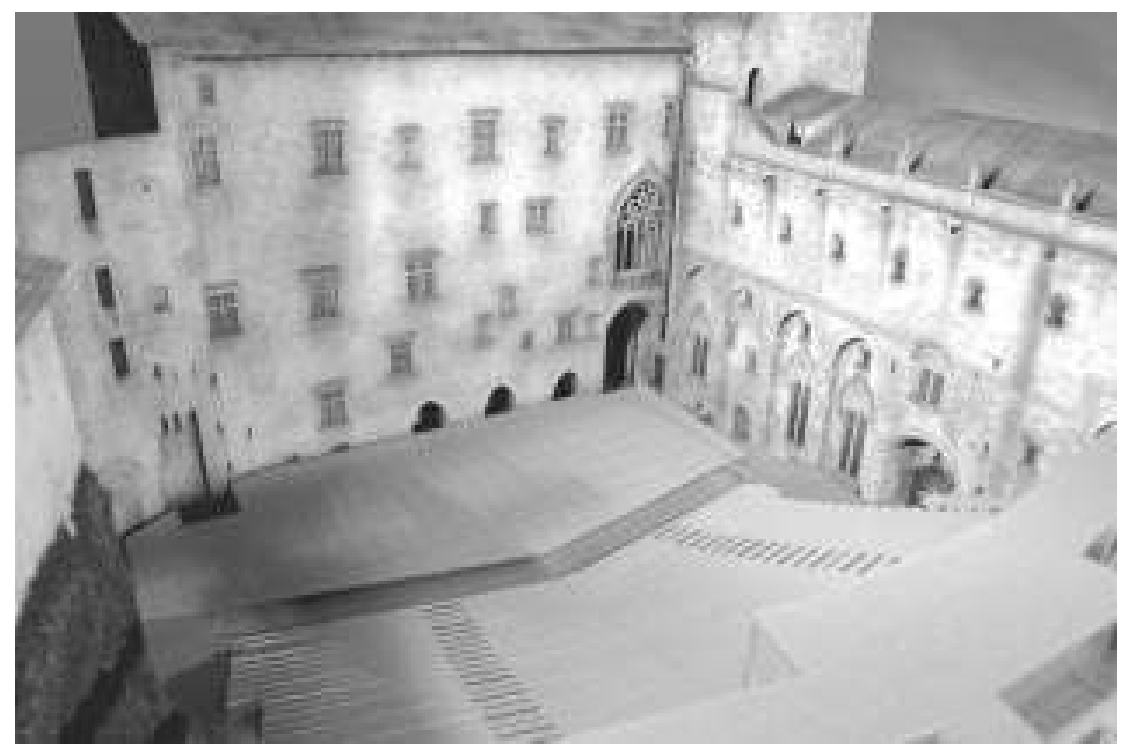

Maqueta do Pátio de Honra de 2002/ângulo 1

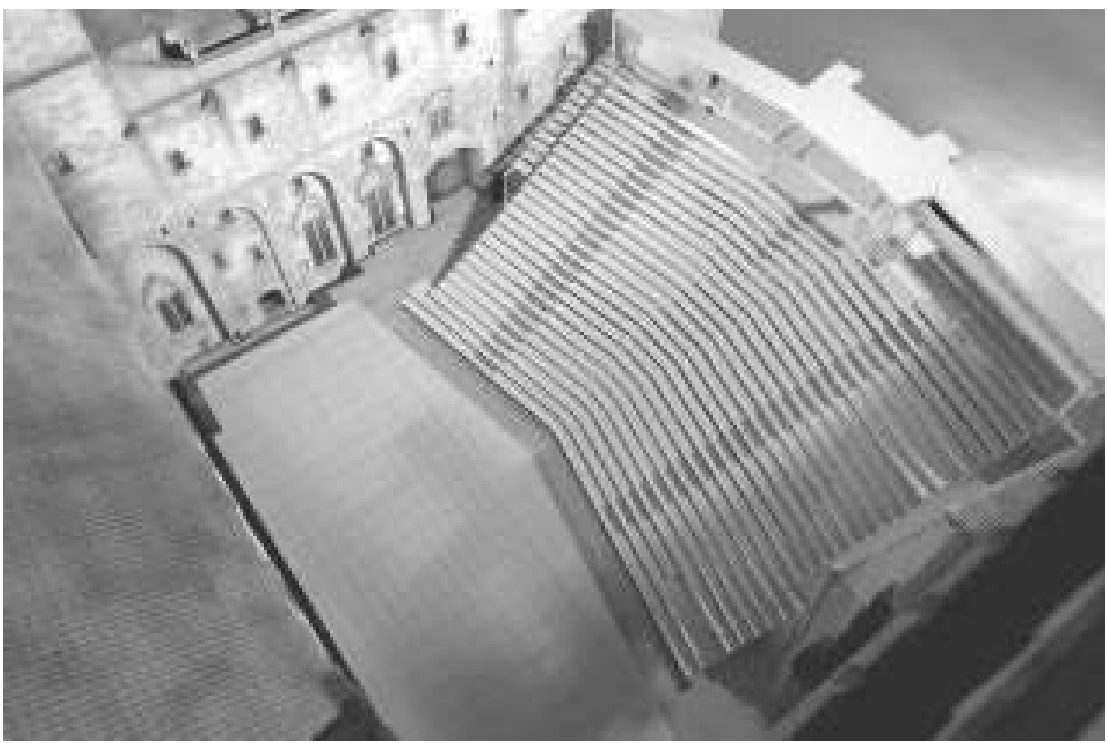

Maqueta do Pátio de Honra de 2002/ângulo 2 
Este novo dispositivo traduz, melhor do que qualquer outro antes dele, a preocupação em apresentar uma obra em cena a uma comunidade de espectadores reunidos num espaço que converge para a uniformização do público. Tanto pela inclinação como pela repartição dos assentos, é realmente uma assembleia unificada aquela que se confronta com o palco e que, desse modo, podemos admiti-lo, poderá ainda mais fortemente confrontar-se consigo própria. Porque esta confrontação é central para que se apreenda o Pátio como um dispositivo. Se o teatro é pensado como o lugar de uma representação, isto é, o lugar onde tornamos uma acção presente ao espírito dos espectadores, graças a toda uma série de artifícios de cena, é preciso perguntar-se com exactidão o que é que tornamos presente neste espaço aparentemente inadequado que é o Pátio. Durante o Festival, é um espaço de teatro, mas um espaço que acarreta consigo uma actualização do texto condicionada por toda a espécie de constrangimentos que o teatro de sala proscreve. Inclusive os que dizem respeito à sala, onde o desconforto imposto pelo Pátio, com as suas noitadas, em que os cobertores são distribuídos à entrada, onde o vento mistral gela as orelhas e as pernas, esse desconforto chama o público a uma condição de espectador activo por necessidade. E esse público não só aceita essas condições, como se agarra a elas para melhor fazer valer a sua opinião, o seu regozijo ou as suas divisões. Quando o espectáculo não se lhe oferece no consenso tranquilo dos grandes clássicos, como aconteceu em 2001 com a obra coreográfica de Jan Fabre, Eu sou sangue, as manifestações deste Pátio activo tornam-se legião e parecem, cada noite, codificadas da mesma maneira. Num primeiro momento, a partir do meio do espectáculo, há quem abandone a cadeira batendo ostensivamente com ela. Primeiro, espectadores isolados, depois, pequenos grupos sucessivos, que, emancipados, procuram o seu caminho na obscuridade do Pátio. O barulho dos que partem é sentido pelos que ficam, e esse barulho vai frequentemente legitimar, dando-lhes segurança, muitas das reacções manifestadas no final do espectáculo. É que Avignon não é nunca um lugar de consenso: a crítica, mesmo a crítica violenta, são consubstanciais ao Festival. Desde há alguns anos, a crítica pontual em torno dos espectáculos deu progressivamente lugar a uma contestação mais geral das próprias funções da manifestação. Convém, por fim, salientar a desconfiança de uma parte da crítica e do mundo do teatro relativamente à forma contemporânea do Festival.

\section{O pessimismo radical e a ilusão de uma idade de ouro}

A crítica ao Festival é tão velha como ele. Há um elemento constante que se apresenta mesmo ao espírito menos atento: os diferentes argumentos 
mobilizam intensamente a história do Festival para avaliar o seu estado presente. A legitimidade de Jean Vilar parece ser a pedra de toque de todo o juízo acerca do presente, como se o projecto do fundador fosse o horizonte inultrapassável da prática teatral. Sente-se uma espécie de paralisia diante do império da hagiografia que constitui os primeiros anos de Avignon como uma "idade de ouro" do teatro em França. Consideremos, por alguns momentos, uma obra recente sobre Jean Vilar (Simon, 2001). Alfred Simon começa por deplorar o estado presente do teatro em França:

Jean Vilar saiu definitivamente de cena em 1971. O Festival de Avignon celebrou a quinquagésima edição em 1996. Trinta anos após a sua morte, podemos interrogar-nos sobre o que resta do fundador no movimento teatral actual, na sua prática artística, no seu funcionamento institucional. Perdura a crise dos textos e dos autores. Nenhum novo Brecht, ou Claudel, ou Ionesco, Becket ou Genet no horizonte. Os novos autores de sucesso (e existem alguns) voltaram a normas de escrita teatral mais conformes a uma tradição não demasiado afastada do "teatro de boulevard". A mais criativa de todas, Yasmina Reza, conseguiu, com a sua peça Art, o primeiro triunfo mundial do teatro francês desde há quarenta anos. Pois bem, a intelligentsia torceu o nariz. (Simon, 2001: 7)

O autor não é de modo algum meigo com os herdeiros directos de Jean Vilar. Evocando os progressos da descentralização teatral e a multiplicação dos equipamentos, Alfred Simon acrescenta:

Poderíamos julgar que Jean Vilar não defendeu em vão a causa do teatro popular e da descentralização dramática... e que a sua utopia está em vias de se realizar trinta anos depois do seu desaparecimento. Longe disso. Todos conjugados, esses talentos que ainda não chegaram aos quarenta anos estão persuadidos de que consumaram o assassínio do pai através da morte desta utopia. Sem ela, já sem saber para que servem, nem para que serve o teatro, tratam de o desconstruir ou de o reconstruir como a um puzzle sem lhe mudar nada. Admitamos que esperávamos outra coisa do caminho aberto por Jean Vilar. (Ibid.: 8)

Deixando ao autor a inteira responsabilidade das suas propostas, podemos citá-lo como referência para ilustrar a versão conservadora da ortodoxia associada a Vilar, que suscita um impasse acerca das condições contemporâneas da produção e da recepção teatral, bem como sobre as formas da concorrência de outros modos de expressão. A verdadeira questão é a do estatuto político do teatro na cidade. O teatro será ainda o medium privilegiado da constituição de um colectivo a partir da reunião pública em 
torno de formas discursivas? Será ainda o lugar por excelência da elaboração da cidadania? Era-o verdadeiramente na época de Vilar? Não é a hagiografia o modo mais seguro de evitar que se coloquem questões cruciais relativamente às formas instituídas de justificação do teatro e do seu flagrante desfasamento com a realidade das práticas? Observando o fosso crescente que separa as práticas de teatro, tal como podem ser descritas pelos sociólogos, das formas de teorização acerca das questões do espectáculo ao vivo que dominam hoje no mundo intelectual e artístico, não podemos senão ficar preocupados.

Se queremos ter uma ideia precisa da posição efectiva que Jean Vilar ocupou no mundo cultural francês do pós-guerra, não é certamente para a hagiografia que nos devemos voltar, mas sim para a história das instituições culturais. Numa obra que fez época, Philippe Urfalino (1996) estudou o complexo processo que conduziu à aplicação da política cultural em França e que fez a singularidade do país no conjunto do mundo democrático. A questão do teatro é central nesta dinâmica da invenção. Philippe Urfalino insiste, em primeiro lugar, contra a leitura "dos anos pós-68" ainda dominante relativamente à questão da democratização cultural, no facto de não estar certo de que a ilusão da igualização das condições no mundo cultural tenha sido inteiramente partilhada. Ele mostra, em particular, que a questão do teatro popular não pode ser reduzida à mitologia simplista à qual foi frequentemente reduzida.

Se o ideal do teatro popular incluía algumas esperanças que podemos, retrospectivamente, julgar ilusórias, como a do povo reunido como espectador, que só a televisão viria a realizar, os homens da descentralização, em graus diversos, estavam já conscientes disso. No seu ideal, eles faziam parte dos fins mais mobilizadores do que acessíveis e das exigências que esses fins induzem. (Urfalino, 1996)

As referências regulares à questão do carácter necessariamente popular do teatro podem ser a expressão de uma forma de "ilusão cívica" que já não convence verdadeiramente ninguém, mas que todos concordam ser útil referir como um princípio de orientação da acção cultural em geral. Sem prejuízo de uma demonstração mais completa, poderíamos pensar, como Philippe Urfalino, que, no início dos anos sessenta, "as miragens do teatro popular tiveram mais incrédulos do que crentes”. Uma tal afirmação pode desembocar na questão fundamental da crença, que Paul Veyne abordou outrora ao colocar a questão: terão os Gregos acreditado nos seus mitos? A proximidade histórica com a vida cultural do pós-guerra, a existência de sobreviventes e a continuidade das referências culturais são, paradoxalmente, 
um obstáculo na busca de resposta à questão sobre se os pioneiros da acção cultural acreditaram verdadeiramente na igualização, a curto prazo, das condições de acesso à cultura ou se eles terão pensado tão-somente que a questão do teatro popular poderia constituir um marco no horizonte da acção. Nesse sentido, a sacralização do primeiro Festival de Avignon, acentuando o carácter quase religioso da ascese de Vilar, tende a ocultar a dimensão laica e racionalista do projecto, e o seu alcance reflexivo e crítico, tão afastado do "utopismo" e do "revolucionarismo".

A investigação histórica pode também fazer ver uma outra ilusão: aquela que veria no Festival de Avignon uma manifestação de absoluta exigência artística, destinada a produzir um novo público. Foi com o público existente que Jean Vilar trabalhou, em Paris como em Avignon. Invocámos já a confiança no programador que o empenho regular dos espectadores implica. Uma tal confiança nunca é, porém, a expressão de um seguidismo cego ou de um abandono. É antes o produto de uma série de trocas nas quais o espectador é sempre activo: o espectador nunca é o produto de um encenador demiurgo. Ele preexiste à representação, sobrevive-lhe e faz ouvir a sua voz. Por existirem limitações específicas das companhias de teatro da descentralização, na província, as preferências do público tiveram frequentemente mais peso do que as exigências artísticas. O peso do Teatro Nacional Popular - dirigido, em Paris, por Jean Vilar de 1951 a 1963 - na programação do Festival até 1966 permite compreender a moderada inovação que caracterizou os "anos-Vilar". Só em 1967, imediatamente antes da agitação de 1968 que haveria de perturbar consideravelmente o desenrolar da manifestação, é que o Festival se abre verdadeiramente a outros teatros, sem, contudo, buscar a provocação do público (Roger Planchon, Jorge Lavelli e Maurice Béjart constam dos cartazes). Aquando do último Festival organizado por Jean Vilar, em 1970, François Périer apresenta O Diabo e o bom Deus, de Jean-Paul Sartre. Não exageramos se dissermos que a programação de Jean Vilar foi constantemente marcada por uma forma de justa prudência, por um sólido apego aos clássicos e pela fidelidade a alguns princípios de encenação estabelecidos desde cedo e rigorosamente seguidos. Uma tal visão do teatro é completamente condizente com a exigência ético-política do teatro como serviço público, mas pouco compatível com uma ideologia defensora da autonomia criadora.

O labor da nostalgia, que encontramos nos conservadores como Alfred Simon, mas também está presente em alguns radicais, interpõe um duplo ecrã entre os contemporâneos e a história de Avignon. Tomando à letra a noção de teatro popular, transforma-se em projecto político o que mais não foi do que uma espécie de ficção teórica destinada a instalar o teatro público 
como uma categoria da acção política. Somos, pois, levados a interpretar de forma enviesada uma história que, relativamente à produção de efeitos sociais por via de aparelhos culturais, é com certeza bem mais modesta do que imaginamos. Sem qualquer prova obtida através de pesquisa empírica, torna-se possível afirmar que o teatro era muito mais democrático nos anos cinquenta do que nos dias de hoje. O segundo ecrã é constituído pela equivalência entre o serviço público e a liberdade do criador. Os constrangimentos específicos do teatro público, em particular na província, levam-no a criar compromissos com os frequentadores que se transformam em outras tantas limitações para o criador. A ilusão da harmonia entre a autonomia do gesto artístico como norma única da prática e a satisfação do público através do levantamento dos constrangimentos económicos que pesam sobre o exercício normal da actividade permite todas as reinterpretações radicais da obra de Vilar. O facto de se fazer contrastar a época actual, que veria a dominação dos gostos do público e as exigências da gestão e do marketing orientarem a programação, com uma idade de ouro da autonomia à maneira de Vilar é a consequência de um equívoco acerca da própria lógica do Festival. Se os pactos entre criadores e público puderam variar ao longo de meio século, não deixa, por isso, de ser verdade que eles constituem uma característica constante da experiência de Avignon, e são eles que lhe conferem sentido. Estes pactos não teriam qualquer sentido se não fossem garantidos pela intensa actividade institucional que os suporta. O Festival é uma instituição, no sentido quasi-durkheimiano do termo: as interacções que se estabelecem durante a manifestação estariam privadas de verdadeiro significado se não fossem certificadas pela instituição. Neste sentido, a presença de eleitos ou de responsáveis institucionais, tão evidente desde as origens até aos nossos dias, funciona como garantia deste vasto espaço de interacções.

\section{Conclusão}

Avignon é demasiadas vezes entendido como um monumento nacional relativamente ao qual todo o trabalho simbólico necessário à sua manutenção está centrado sobre uma forma de utopia política. A realidade é, sem dúvida, mais diversa e merece um desdobramento da atenção sociológica no sentido do que faz a vibração própria da manifestação, que deve muito da sua especificidade às temporalidades e aos ritmos que engendra. A análise do material recolhido até hoje no terreno de Avignon deve ser confrontada, num futuro próximo, com outros contextos de experiência teatral, com outras formas de percursos culturais. O nosso objectivo era, aqui, contribuir para a reterritorialização da investigação sobre as práticas culturais: pare- 
cia-nos que, ao longo do tempo, esta tinha sido sobrecarregada com conteúdos ideológicos e aliviada de uma boa parte das questões empíricas interessantes que podia suscitar. Mais do que nunca, parece-nos que a sociologia da cultura constitui um espaço pertinente para pôr à prova a validade das conceptualizações sociológicas. No entanto, as ocasiões que temos para colocar as boas questões são muito raras: somos remetidos, com demasiada frequência, para a confrontação estéril entre as teorias sociológicas tornadas rotineiras e a ideologia profissional dos operadores da cultura (gestores e parceiros de todo o género). O facto de o exame regular dos dados recordar a força da estratificação social das actividades culturais não deve levar-nos a considerar fatigantes ou repetitivas as constatações cuja única característica é serem verdadeiras. Se não propomos uma conceptualização alternativa às problemáticas da distinção ou da dominação cultural, sob a forma de "teoria geral", não é por falta de ambição: consideramos apenas que o excesso teórico é uma ameaça para um espaço de investigação ainda caracterizado pela fragilidade. A difusão de uma teoria definitiva da cultura constitui, quando esta se banaliza e cai no domínio público, um obstáculo significativo para a investigação empírica, cuja função é então reduzida à ilustração de teses já estabelecidas.

Descentralizado numa cidade que não é um dos grandes pólos urbanos franceses, e concentrado num curto período estival, o Festival não pode ser inteiramente avaliado a partir dos efeitos de "notabilidade cultural" nem mesmo de distinção. O grande número de funcionários e de intelectuais que pertencem ao serviço público entre os participantes do Festival dá uma boa ideia da associação entre uma população de espectadores e uma ideologia do teatro como "serviço público", para utilizar a expressão forjada pelo próprio Jean Vilar. Embora as condições objectivas do acesso às obras e a natureza da oferta tenham sofrido uma profunda transformação, desde o imediato pós-guerra, percebe-se que há uma nítida continuidade com o Festival dos primórdios. Cabe ao Pátio de Honra o papel de um verdadeiro e paradoxal traço de união histórica, mas também espacial, constituindo o espaço comum onde tem lugar a sucessão de gerações e ocorre a possibilidade de uma história coerente, de uma memória do teatro inscrita numa experiência original de urbanidade.

O Festival de Avignon apresenta uma forte identidade. Para lá da multiplicação da oferta, da heterogeneidade das formas de atenção ou de disciplina do corpo que os diferentes espectáculos implicam, constitui-se um espaço comum que permite falar do público de Avignon no singular, como forma de compromisso entre o divertimento e a ideologia que a hagiografia dos momentos da fundação ajudou a impor. Tal como outras formas cultu- 
rais, o Festival de Avignon é uma composição, nunca verdadeiramente estabilizada, de definições impostas e de compromissos inéditos. Mais do que em qualquer outro lugar, existe uma dinâmica da tensão entre o sentimento anti-institucional que habita toda a ambição criadora (e também, de forma muito similar, a implicação do espectador) e o desejo de instituir e de estabilizar, ou mesmo de tornar perene, uma forma de equilíbrio entre uma oferta e um público cuja existência, enquanto comunidade, depende da força de uma proposta institucional. Esta tensão é consubstancial ao Festival: ela explica, simultaneamente, o alargamento permanente das suas periferias contestatárias e a integração, igualmente regular, das margens na proposta institucional. É o que explica que as interrogações sobre o declínio de Avignon e as reacções da instituição constituam elementos essenciais da vida do Festival. Lugar de deleite, mas também de indignação, incomparáveis arenas da luta pela definição do espectáculo ao vivo e das relações que mantém com colectivos de espectadores, o Festival permanece um lugar onde o conjunto dos protagonistas brinca aos habitués de festivais, e onde, de maneira mais ou menos visível, as novas gerações são postas à prova na sua condição de espectador e contribuem para modificar indefinidamente as regras do jogo.

Tradução de

João Domingues

\section{Referências Bibliográficas}

Abirached, Robert (1992), "Des premières semailles aux premières réalisations. Les précurseurs: Jacques Copeau et sa famille”, in R. Abirached (org.), La décentralisation théâtrale - 1. Le premier âge, 1945-1958. Arles: Actes-Sud.

Arlaud, Catherine (1969), Le Festival d'Avignon 1947-1968. Paris (diss. de doutoramento). Banu, Georges (1993), Le théâtre ou l'instant habité. Paris: L'Herne.

Beaudouin, V.; Maresca, B. (1998), Les publics de la Comédie française. Paris: La Documentation Française.

Éthis, Emmanuel (org.) (2002), Avignon, le public réinventé. Le Festival sous le regard des sciences sociales. Paris: La Documentation Française.

Guy, Jean-Michel (1991), Les publics de la danse. Paris: La Documentation Française. Guy, Jean-Michel; Mironer, Lucien (1988), Les publics du théâtre: fréquentation et image du théâtre dans la population française agée de 15 ans et plus. Paris: La Documentation Française.

Larrue, Janine (1968), “Le public du Festival d'Avignon 1967”, Avignon-Expansion, printemps. 
30 | Jean-Louis Fabiani e Emmanuel Éthis

Lerrant, Jean-Jacques (1996), "Le public, un et multiple. Ode à la nuit”, in Avignon, 50 festivals. Arles: Actes-Sud.

Ory, Pascal (1994), La belle illusion. Culture et politique sous le signe du Front Populaire. Paris: Plon.

Simon, Alfred (2001), Jean Vilar. Tournai: La Renaissance du Livre.

Singly, François de; Thélot, Claude (1989), Gens du public, gens du privé. La grande différence. Paris: Dunod.

Urfalino, Philippe (1996), L'invention de la politique culturelle. Paris: La Documentation Française.

Vilar, Jean (1953), Théâtres de France, III.

Vilar, Jean (1968), “Introduction à l'enquête de Janine Larrue”, Avignon-Expansion, printemps. 